\title{
A RÓMAI STATÚTUM RENDELKEZÉSEI HARMADIK ÁLLAMOK VONATKOZÁSÁBAN
}

\author{
The provisions of the Rome Statute in connection with Third \\ States
}

Pesci Marco ${ }^{1}$

\begin{abstract}
Absztrakt: A Nemzetközi Büntetőbíróságot életre hívó 1998. évi Római Statútum a XX. század egyik legjelentősebb dokumentuma, amely méltán reprezentálja a nemzetközi közösség célkitűzését: a nemzetközi közösség egészét érintő bűncselekmények elkövetőinek felelősségre vonását, és a prevenció tényleges megvalósítását. A Bíróság 2002-es múködésének megkezdése óta kilenc személy büntetőjogi felelősségét állapította és további 21 személlyel szemben van folyamatban eljárás. Jóllehet, hogy a Bíróság felállítása a nemzetközi büntetőjog egyik legnagyobb eredménye, azonban a Római Statútum elfogadásának 20. évfordulóját követően érdemes értékelni azokat az anomáliákat, amelyek eddigi múködése során napvilágra kerültek. Ahogy azt az elmúlt évszázad során megtapasztaltuk, a nemzetközi bűncselekmények elkövetésében az állami hierarchiában legmagasabb pozíciót betöltő személyek közvetve vagy közvetlenül jelentős szereppel rendelkeznek, akik az őket megillető immunitásból kifolyólag jóformán érinthetetlennek tekinthetőek. Mindezekből kifolyólag a Statútum - a nemzetközi közjog fejlődésével összhangban - expressis verbis rögzíti a hivatalos minőség irrelevanciáját. Ugyanakkor, mint egy nemzetközi szerződés, fő szabály szerint nem állapíthat meg kötelezettségeket egy harmadik állam terhére annak beleegyezése nélkül. Kérdésként merül fel, hogy mit tehet a Bíróság, ha egy harmadik állam hivatalban lévő államfőjével szemben kíván eljárást lefolytatni? Mivel a Bíróság önálló erőszakszervezettel nem rendelkezik, így a tagállamok együttmúködésére van utalva
\end{abstract}

\footnotetext{
1 A szerzőről: ${ }^{1}$ Pesci Marco a Debreceni Egyetem Márton Géza Állam és Jogtudományi Doktori Iskola doktorandusz hallgatója, a Külgazdasági és Külügyminisztérium Nemzetközi Jogi Főosztályának jog referense. E-mail: marcopesci94@gmail.com Jelen tanulmányt a szerző kutatói minőségben készítette, és az nem tekinthető a Külgazdasági és Külügyminisztérium hivatalos álláspontjának.
} 
akiket a Statútum mellett, a nemzetközi közjogból származó egyéb kötelezettségek is terhelnek, mint például az államfői immunitás tiszteletben tartása. Ezen kérdés megoldásának problémájával szembesült a Bíróság, amikor az ENSZ BT 1593. számú határozata alapján elfogató parancsot bocsátott ki Omar al-Bashir szudán elnöke ellen, aki ennek ellenére számos alkalommal tartózkodott egy részes tagállam területén. Jelen tanulmányban a Római Statútum vonatkozó rendelkezéseinek értelmezésén át kívánom feltárni az ICC hatáskörének korlátait.

Kulcsszavak: Nemzetközi Büntetőbíróság, Szudán, Omar Al-Bashir, immunitás, Római Statútum, 27. Cikk, 98. Cikk, UNSC Res. 1593., nemzetközi közjog, nemzetközi büntetőjog

Abstract: The Rome Statute of 1998 is one of the most important documents of the 20th century which represents one of the main objectives of the international community, namely to end the impunity of the perpetrators of the most serious crimes of human concern. It is true, that the creation of the ICC is one of the most fundamental steps of international criminal law, however, after the 20th anniversary of the Rome Statute it is important to evaluate the anomalies which occurred during its functioning. As the international community experienced during the past centuries, the perpetrators of the international crimes are generally an official in the highest rank of the state hierarchy. As of consequence, they enjoy personal immunity therefore they can not be prosecuted. In conformity with the evolution of international law, the Statute expressis verbis declares the irrelevance of official capacity. However, the Statute as an international treaty can not confer obligations to a third state without is prior consent. What can the ICC do, if the subject of the prosecution is a head of state in office of a third state? As the ICC do not posses an independent executive body, it has to rely on the cooperation of States Parties, which have obligations under public international law other than the Statute itself, such as the obligation to respect the personal immunities of state officials. This was the main issue in the case of Omar Al-Bashir, whose arrest was ordered after the Resolution 1593. of the United Nations Security Council. Nonetheless of the arrest warrant, al-Bashir travelled to the territory of several States Parties, which under the Statute had the obligation to arrest him. In this study, I intend to explore the limits of the ICC's jurisdiction by interpreting the relevant provisions of the Rome Statute 
Keywords: International Criminal Court, Omar Al-Bashir, immunity, Rome Statute, Article 27, Article 98, UNSC Res. 1593., public international law, international criminal law

\section{BEVEZETÉS}

Több mint hét évtized telt el a nürnbergi perek óta, mely időszak alatt a nemzetközi közjog számos rendkívül fontos fejlődési fokon ment keresztül. A második világháborút követően a nemzetközi közösség ténylegesen kimutatta az erős és effektív együttműködés iránti igényét és elfogadta annak szükségességét. ${ }^{2}$ A büntetőjog területén ugyanakkor a szorosabb nemzetközi együttmúködés megvalósulása sokáig váratott magára. Ennek oka, hogy a büntető államhatalmi tevékenység gyakorlása az állami szuverenitás egyik legfontosabb eleme, ${ }^{3}$ melyből kifolyólag a szuverenitás védelme és az eljárás hatékonysága közötti egyensúly megteremtése elengedhetetlen feltételként jelentkezett. ${ }^{4}$

Az ENSZ keretein belül számos büntető fórum felállítására sor került, amelyek mindenképpen áttörést jelentettek a nemzetközi közjog korábban létező normáin. ${ }^{5}$ A nemzetközi közjog jogi természetéből adódóan, mely döntően az államok közötti kapcsolatokat szabályozza, elsődleges feladat volt az egyén nemzetközi jogalanyiságának elismerése, mivel a büntetőjog alapvetően az individuumra fókuszál. Bár kétségkívül jelentős áttörést jelentettek ezek a fórumok, komoly hiányosságuk volt az általános joghatóság hiánya.

Az igazi áttörés csak a XX. század végén született meg, amikor a nemzetközi közösség akarata egy állandó nemzetközi büntetőbíróság létrehozásában manifesztálódott a Nemzetközi Büntetőbíróság Statútumának 1998-as elfogadásával. ${ }^{6}$ A Római Statútum (a továbbiakban: Statútum) végleges szövegének elfogadása során addig példanélküli egyetértésben, a kodifikálásban résztvevő 148 államból 120 támogatta annak

\footnotetext{
2 FRAY - KUNKEL - UNGER, 2014. 2.o.

3 VARGA, 2006. 96.o.

${ }^{4}$ CASSESE, 2008. 20.o.

5 INTERNATIONAL CRIMINAL TRIBUNAL FOR THE FORMER YugOSLAVIA, 1993., INTERNATIONAL CRIMINAL TRIBUNAL FOR RWANDA, 1994., SPECIAL COURT FOR SiERRA LEONE, 2000.
}

${ }^{6}$ DANILENKO, 2000. 445.o. 
szövegét. ${ }^{7}$ Ennek köszönhetően létrejött az első független és állandó Nemzetközi Büntetőbíróság (a továbbiakban: ICC), ${ }^{8}$ amely a szuverén államhatalom egyes elemeinek önkéntes átadásán alapszik. ${ }^{9}$ A Statútum 2002. július 1-jén lépett hatályba, amelyet ezidáig 138 állam ratifikált. ${ }^{10}$

Jóllehet, hogy az ICC felállítása a nemzetközi büntetőjog egyik legnagyobb eredménye, azonban a Római Statútum elfogadásának 20. évfordulóját követően érdemes értékelni azokat az anomáliákat, amelyek eddigi múködése során napvilágra kerültek. A Statútumot ratifikált államok közül a maga 26\%-ával az afrikai kontinens kiemelkedő szereppel rendelkezik. Ezen országokat összefogó Afrikai Unió (a továbbiakban: AU) teljes mértékben támogatta az ICC felállítását, azonban eddigi jól múködő kapcsolatuk az utóbbi évtized folyamán jelentős visszaesésen ment keresztül.

Az ENSZ Biztonsági Tanácsa (a továbbiakban: ENSZ BT) az Alapokmány VII. fejezete alapján eljárva, 1593. számú határozatával utalta a Statútumban nem részes, Szudán Dárfúr régiójában történt események kivizsgálását az ICC hatáskörébe. Ennek alapján letartóztatási parancsot adott ki Szudán de facto és de jure elnöke, Omar Hassan Ahmad al-Bashir ellen két rendbeli háborús bűncselekmény, öt rendbeli emberiesség elleni bűncselekmény és három rendbeli népirtás vádjával. Al-Bashir a letartóztatási parancs ellenére több alkalommal utazott egy, a Statútumban részes állam területére. Ezek az államok ${ }^{11}$ a Statútum 86. cikke alapján kötelesek lettek volna letartóztatni. A Tárgyalás-előkészítő Tanács Malawi, Csád, Kongó, Szudán, Uganda, Djibouti, Dél-Afrikai Köztársaság és a Jordániában tett látogatását alapul véve állapította meg az együttműködési kötelezettség megszegését, az ügyet pedig az ENSZ BT és a Szerződő Államok Közgyűlése elé utalta. Az AU kérvényezte, hogy az ICC függessze fel az al-Bashir ellen indított eljárást a szudáni békefolyamatok hatékony lefolytatása érdekében, azonban az ICC ezt elutasította. Ennek eredményeképp az AU felszólította tagállamait az együttműködés kötelezettség ignorálására. ${ }^{12} \mathrm{Az}$ érintett tagállamok és az AU az együttmúködési kötelezettség megszegésével kapcsolatos vád ellen a 27. és a 98. cikk közötti

\footnotetext{
7 UN PRESS RELEASE, 1998.

${ }^{8}$ ROACH, 2013. 507.o.

${ }_{9}$ SCHUERCH, 2017. 2.o.

${ }^{10}$ Rome StATUte of THE INTERnAtional CRIMINAL COURT, 1998.

${ }^{11}$ Malavi, Csád, Kongó, Szudán, Uganda, Djibouti, Dél-Afrika, Jordánia

12 Assembly of the African Union, 2009.
} 
ellentétre hivatkozott az utóbbi javára. Az ICC ugyanakkor érvelésüket elutasította, és a mai napig sem adott egyértelmű választ a Statútumban meglévő ellentétre harmadik államok államfői immunitásának vonatkozásában.

\section{AZ ÁLLAMFŐI IMMUNITÁS HATÁSA A BÜNTETŐJOGI FELELŐSSÉGRE VONÁSRA}

\subsection{Immunitás, mint eljárásjogi akadály}

Az államfők büntetőjogi felelősségének tekintetében ellentmondásos, hogy vajon immunitásuk anyagi jogi természettel rendelkezik-e, és így felelősségüket abszolút kizárja, vagy csupán eljárásjogi akadályként értelmezendô.

Funkcionális immunitás esetében, amennyiben tevékenysége állami cselekedetnek minősül, úgy nem az egyént, hanem magát az államot terheli felelősség. ${ }^{13}$ Ezt az álláspontot tükrözi a Jugoszláv ad-hoc Törvényszék Tihomir Blaškić ügyében hozott itélete. ${ }^{14}$ Amennyiben tevékenysége nem minősül állami aktusnak, úgy felelősségre vonásának eljárásjogi akadálya nincs. Ezzel ellentétben, a személyi immunitás csupán egy eljárásjogi akadály jelent, mely az egyén büntetőjogi felelősségét nem érinti. ${ }^{15}$ Mindazonáltal a Nemzetközi Bíróság (International Court of Justice, a továbbiakban: ICJ) a letartóztatási parancs ügyében hozott ítéletében kiemelte, hogy az immunitás nem jelent büntethetőséget kizáró okot, az immunitás és büntetőjogi felelősség két, teljes mértékben különböző koncepció. ${ }^{16} \mathrm{Az}$ immunitás fő funkciója, legyen az akár személyi vagy funkcionális, az állam hatékony képviseletének biztosítása, melynek eljárási akadályként teljes mértékben képes megfelelni. ${ }^{17}$

A nemzetközi büntetőjog álláspontja ebben a kérdésben egyértelmű: biztosítani, hogy a nemzetközi közösség egészét érintő legsúlyosabb bűntettek ne maradjanak büntetlenül és véget vetni e bűntettek büntetlenségének, ezáltal biztosítva a prevenciót. ${ }^{18}$ Ugyanakkor az immunitás, mint

\footnotetext{
13 i.m. CASSESE (2008) 304.

14 Prosecutor V TiHomir BlašKiĆ, 1997. 38.o.

15 i.m. WERLE, 2014. 648.o.

16 i.m. CASSESE, 2002. 60.o.

17 i.m. AMBOS, 2013. 410.o.

18 RÓmai STATÚtum, PREAmbulum
} 
eljárásjogi akadály elismerése ellentmond a most responsible doktrínájának, mivel ezek a személyek általában katonai és politikai vezetôk, akik az állami immunitás ernyője alá bújva főszabály szerint mentességet élveznek. ${ }^{19}$ Ennek tekintetében három irányvonal különíthetô el az immunitás és a büntetőjogi felelősség összeegyeztetésének vonatkozásában.

Az első, mely szerint egy nemzetközi bủncselekmény elkövetése vagy arra történő utasítás nem minősíthető állami tevékenységnek, mivel egyrészt nem tartozik az állami feladatok körébe, másrészt nem minősíthető olyan tevékenységnek, amelyet egy állam legitimen módon foganatosíthat. Ugyanakkor ez az álláspont több szempontból is hibás. Egyrészt, a nemzetközi bủncselekmények elkövetői és támogatói rendszerint államok, mely értelemszerūen magában foglalja a politikai és katonai tevékenységeket, mint a szuverén aktusok iskolapéldáját. ${ }^{20}$ Ezt az álláspontot az ENSZ a kínzás és más kegyetlen, embertelen vagy megalázó büntetések vagy bánásmódok elleni egyezményének 1 . cikke egyaránt megerősíti, ${ }^{21}$ mely egy állami tisztviselő hivatalos minőségben történő eljárását feltételezi. ${ }^{22}$ Továbbá, amennyiben egy nemzetközi bűncselekményt kizárólag magántevékenység keretében lehet elkövetni, úgy az adott cselekmény nem kapcsolható az államhoz, mely kizárja annak felelősségét és a kompenzáció fizetésének lehetôségét. ${ }^{23}$

A második elmélet szerint a nemzetközi bűncselekmények és azok büntetőjogi felelőssége is ius cogens normatív alappal rendelkezik. ${ }^{24}$ Ugyanakkor a nemzetközi jog hierarchiája alapján, az egyes normák különböző módon funkcionálnak, így a ius cogens szabályok, mint anyagi jogi normák az eljárásjogi kérdéseket nem érintik. ${ }^{25}$

A harmadik hipotézis a nemzeti bíróságok extraterritorialitása és a funkcionális immunitás közötti ellentétre fókuszál: az előbbi eljárást követel meg, míg az utóbbi kizárja annak lehetőségét. A lex posterior derogat legi priorikésőbbi jogszabály lerontja a korábbit - elve alapján az extraterritorialitás, mint későbbi jogszabály derogálja az immunitást. ${ }^{26}$ Ugyanakkor a teljesen

\footnotetext{
${ }^{19}$ REYDAMS - WOUTERS - RYNEGAERT, 2012. 522.o.

20 i.m. CRYER, 2010. 540.o.

21 Convention Against Torture And Other Cruel, InHuman or Degrading TREATMENT OR PUNISHMENT, 1984.

22 CASSESE, 2002. 868.o.

23 SPINEDI, 2002. 898.o.

${ }^{24}$ KALECK, 2007. 72.o.

25 JURISDICTIONAL IMMUNITIES OF THE STATE, 2012. 93.o.

26 i.m. AKANDE, 2011. 840.o.
} 
formális megközelítés bizonytalanságot eredményez, mely veszélybe sodorja a jogbiztonságot. ${ }^{27}$

A XXI. században a szuverenitás csupán 'takaró immunitásként' értelmezhető, mely, - amennyiben nem derogálható - kizárja az emberiség legsúlyosabb bűncselekményeiben érintett személyek felelősségre vonását és súlytalanná teszi a nemzetközi közösségnek a korábbi évszázadok szörnyűséginek megakadályozásának érdekében tett lépéseit. Kétségtelen, hogy az immunitás abszolút kizárása felborítaná a nemzetközi kapcsolatok stabilitását, ${ }^{28}$ ugyanakkor a lehetôség elvetése azt az üzenetet közvetítené, hogy minél magasabb a pozíció az állami hierarchiában, annál kisebb a felelősség. E lehetőségeket felismerve és a büntetlenség kultúrájának felszámolása céljából valamennyi ma ismert nemzetközi büntetőbíróság statútuma explicit módon rögzíti a hivatali státusz irrelevanciáját. Ennek megfelelően a személyi immunitást eljárásjogi akadályként értelmezhetjük, míg a funkcionális mentelmi jog anyagi jogi kifogásként funkcionál. ${ }^{29}$

Az egyedüli kérdés, hogy mikor és hogyan lehetséges az eljárás megindítása. Ennél a pontnál az út kétfelé ágazik: vertikális- és horizontális immunitásra.

\subsection{Horizontális immunitás - nemzeti büntetőbíróságok}

A tradicionális államközi, nemzetközi jog semmilyen kivételt nem enged az állami immunitás tekintetében, melyet megerősít az ICJ Yerodiaügyében hozott ítélete. Ugyanakkor a Jugoszláv ad hoc törvényszék döntése alapján, a nemzetközi bűncselekmények elkövetéséért felelős személyek nem hivatkozhatnak immunitásukra sem nemzeti, sem nemzetközi bírói fórumok előtt. ${ }^{30}$

Számos esetben az immunitás kifogása elutasításra került, azonban annak jogalapját nem az elkövetett búncselekmény adta. Otto Abetz ${ }^{31}$

\footnotetext{
27 i.m. AMBOS, 2013. 413.o.

28 ZAPPALA, 2001. 607.o.

29 i.m. CASSESE, 2002. 863.o.

30 i.m. Prosecutor V TIHOMIR BlašKIĆ, 1997. 41.o.

31 Otto Abetz (1903.03.26. - 1958. 05.05.) a náci Németország franciaországi nagykövete volt 1940-44 között. Legfőbb feladata a Vichy-kormánnyal való kapcsolattartás, valamint a megszállt Franciaország politikai és katonai stabilitásának megőrzése. 1949-ben a Francia igazságszoláltatás emberiesség elleni bủncselekmények elkövetésében bűnösnek találta különös tekintettel a franciaországi zsidók deportálásában - és 20 éves börtönbüntetésre ítélte. Letartóztatását követően úgy nyilatkozott, hogy Hitler életben van. Később e
} 
ügyében a Francia Legfelsőbb Bíróság elismerte a diplomáciai immunitást, mint a háborús bűncselekmények felelőssége alóli mentességet, azonban megállapította, hogy a bűncselekmény elkövetésének idejében Abetz nem rendelkezett akkreditációval a francia kormány részéról, így immunitásra nem volt jogosult. ${ }^{32}$ Ferdinand Marcos, a Fülöp-szigetek volt államföjének immunitását országának új kormánya visszavonta, ${ }^{33}$ Manuel Noriegát pedig az Egyesült Államok nem ismerte el, mint Panama államfőjét, ${ }^{34}$ ezáltal nyílt meg az eljárás lefolytatásának lehetősége. A horizontális mentelmi jog tekintetében a brit Lordok Háza hozta meg a doktrinális fordulatot a Pinochet-ügy keretében. ${ }^{35}$

\subsection{Vertikális immunitás - nemzetközi büntetőbíróságok}

A nemzetközi büntetőbíróságok előtt az immunitás, mint pergátló kifogás nem tekinthető érvényes védekezésnek. ${ }^{36}$ A Nürnbergi Katonai Törvényszék Statútumának 7. cikke - harmadik Nürnbergi elv - volt az első olyan nemzetközi okmány, mely kimondta, hogy a vádlott hivatalos tisztsége, legyen akár államfői vagy a kormányzatban betöltött felelős pozíció, nem tekinthető büntethetőséget kizáró oknak, vagy a büntetés kiszabásánál figyelembe veendő tényezőnek. ${ }^{37}$

Ugyan a Nürnbergi Katonai Törvényszék működését számos kritika érte, kiváltképp a nullum crimen sine lege elvének megsértése miatt, az ENSZ Közgyưlése 1946-ban megerősítette, hogy a Törvényszék Alapokmányban és az itéleteiben foglalt jogelvek a nemzetközi szokásjog részét képezték. ${ }^{38}$ 1950-ben a Nemzetközi Jogi Bizottság pedig részletekbe menően definiálta a nürnbergi alapelveket, nevezetesen, az állami tisztviselők immunitásának tagadását és az elöljárói parancs irrelevanciáját. ${ }^{39}$

nyilatkozata az FBI nyomozati anyagában is megjelent, amely Hitler állítólagos Argentínába szökését vizsgálta.

32 ABETZ, 1951. 482.o.

33 LAUTERPACHT - GREENWOOD - OPPENHEIMER, 1996. 204.o.

34 UNited STATES OF AMERICA V MANUEL ANTONIO NORIEGA

35 i.m. SCHABAS, 2011. 361.o.

36 The Prosecutor v. Omar Hassan Ahmad Al Bashir, 2011. 22-35.o.

${ }^{37}$ CHARTER OF THE INTERNATIONAL Military TRIBUnAL, 1945.

38 AfFirmation of the Principles of International LAW RECOGNIZED BY THE Charter of THE NuRnBERG TribunaL, 1946.

39 YeArboOK OF THE INTERNATIONAL LAW COMMISSION, 1950. 374-378.o. 


\section{A NEMZETKÖZI BÜNTETŐBÍRÓSÁG ÉS AZ ÁLLAMFŐI IMMUNITÁS}

\subsection{A Római Statútumról általában}

Az ICC időbeli joghatóságát a Statútum 11. cikke szabályozza. Ennek értelmében joghatósága a hatályba lépése - 2002. július 1. - után elkövetett bűncselekményekre terjed ki. Tárgyi joghatósága a nemzetközi közösség egészét érintő legsúlyosabb bűncselekményeket érinti, amelyek az 5. cikk alapján a következôk: a népirtás bủntette; az emberiesség elleni bủncselekmények; a háborús bűntettek; az agresszió bủntette. A komplementaritás elvének értelmében csupán akkor járhat el, ha az adott büncselekmény kivizsgálását azon állam, mely joghatósággal rendelkezik az eset kivizsgálására, nem tudja, vagy nem kívánja foganatosítani. ${ }^{40}$ Másrészt, joghatósága főszabály szerint kizárólag a részes államok területén és/vagy valamely részes állam állampolgára által elkövetett bűncselekményekre terjed ki.

Tovább árnyalja az ICC joghatóságának kérdését az eljárások megindításának rendje. A 13. cikk értelmében erre három módon van lehetôség: valamely részes állam utalja az adott ügyet a föügyész elé, a föügyész indít nyomozást, vagy az ENSZ BT utalja az esetet az ICC elé. Ennek alapján látható, hogy főszabály szerint a részes államok állampolgárival szembeni eljárások lehetősége érvényesül, kivételes esetben azonban olyan bűncselekmények esetén is eljárhat, amelyet egy nem részes tagállam területén és/vagy nem tagállam állampolgárai követtek el. Ily módon egy harmadik tagállam eseti alávetési nyilatkozattal elismerheti az ICC joghatóságát, vagy az ENSZ BT VII. fejezete szerinti eljárásban hozott kötelező határozata alapján lehetőség nyilik harmadik államok polgárait érintő eljárások lefolytatására. Ugyanakkor szükséges megjegyezni, hogy sok esetben a nemzetközi bủncselekmények elkövetésért felelős személyek az állami hierarchia legmagasabb fokán foglalnak helyet, így főszabály szerint mentességet élveznek az immunitás esernyője alatt. ${ }^{41}$ Mindezekből kifolyólag a Statútum 2 különálló rendelkezésben szabályozza az immunitás kérdéskörét.

\footnotetext{
40 LATTMANN, 2011. 48.o.

${ }^{41}$ PAPP, 2015. 34.o.
} 


\subsection{A Statútum 27. cikke ${ }^{42}$}

Míg a 27. cikk (1) bekezdése a funkcionális immunitás kérdéskörét tárgyalja, addig a (2) bekezdés a személyi immunitás irrelevanciáját mondja ki. ${ }^{43}$ Nyilvánvalóvá teszi, hogy a Statútum 5. cikkében meghatározott, valamely bűncselekmény elkövetésének gyanúja esetén, a gyanúsított személy büntetőjogi felelősségére az általa betöltött hivatalos pozíció befolyással nem rendelkezik, ezáltal az ICC joghatósága főszabály szerint megállapítható. ${ }^{44}$ Ezen rendelkezés a nemzetközi szokásjog deklaratív megnyilvánulásának tekinthetô, mely nemzetközi bűncselekmények esetén kizárja a funkcionális immunitás intézményét, ${ }^{45}$ és megerôsíti a személyi immunitás irrelevanciáját. ${ }^{46}$

A ratione materiae mentelemi jog felfüggesztésének már egészen a nürnbergi perek óta egy lineáris skálán haladó nemzeti és nemzetközi gyakorlata figyelhetô meg. ${ }^{47}$ Ezt az álláspontot erősíti meg a Jugoszláv ad hoc Törvényszék Slobodan Milošević ügyében hozott ítélete, melyben kifejtette, hogy az ICTY Statútumának 7. cikk (2) bekezdése a nemzetközi szokásjogot testesíti meg. ${ }^{48}$ Amíg a nemzeti bíróságok gyakorlata a funkcionális immunitás tekintetében nyitott kérdésként kezelendő, addig egy tisztviselő hivatalos minősége nem mentesít a büntetőjogi felelősségre vonás alól egy nemzetközi büntető fórum előtt. Ezt erősíti meg az ICTY Radislav Krstić ügyében hozott állásfoglalása: „lehetséges, hogy államok között kapcsolatok esetében léterik a funkcionális immunitás $\{\ldots\}$ ugyanakekor nem helyénvaló azt állitani, bogy ilyen mentelmi jog nemzetközi büntetó fórumok elött is alkalmaz̧atô".

42 „27. C: 1. A jelen Statútum a hivatalos minőségre való tekintet nélkül egyaránt vonatkozik minden személyre. Semmilyen körülmények között sem mentesíti az adott személyt a jelen Statútum szerinti büntetőjogi felelősség alól különösen az állam- vagy kormányfői tisztséggel, kormány- vagy parlamenti tagsággal, választott képviselői vagy kormányhivatalnoki tisztséggel járó hivatalos minőség, és mint olyan, nem indokolja a büntetés mérséklését. 2. A nemzeti vagy a nemzetközi szabályok szerint a hivatalos minőséggel járó mentességek, vagy különleges eljárási szabályok nem akadályozzák a Bíróságot az adott személy fölött joghatóságának gyakorlásában.”

43 SUMMERS, 2006. 490.o.

44 i.m. KING, 2006. 276.o.

45 i.m. Prosecutor V TIHOMIr BlašKić, 1997. 140.o.

46 TRIFFTERER, 2008. 1062.o.

47 PEDRETTI, 2015. 167.o.

48 Prosecutor v. Slobodan Milosevic, 2001, 28.o.

49 Prosecutor V. Radislav Kristic, 2001. 26.o. 
Amíg a funkcionális immunitás kérdése nemzetközi büntetőbíróságok tekintetében lényegtelen és ez által az (1) bekezdés a szokásjog deklaratív megnyilvánulásának tekinthető, a nemzetközi jogirodalom viszonylag egyértelmű álláspontot képvisel, addig mindez a személyi immunitás vonatkozásában nem mondható el. A ratione personae mentelmi jog irrelevanciája a Sierra Leone-i különleges bíróság Charles Taylor ügyében hozott ítéletében jelent meg először.

Ezen álláspontot tükrözi a 27. cikk (2) bekezdése, amelynek célja az ICC joghatóságának biztosítása olyan személyek esetében, akik hivatalos státuszukból eredően személyi immunitás jogosultjai. ${ }^{50}$ Mivel a (2) bekezdés explicit módon nemzeti és nemzetközi jogra hivatkozik, így a szokásjogi szabályok által nyújtott mentelmi jogosultság relevanciával nem rendelkezik. ${ }^{51}$ A 27 . cikk a fentebb kifejtett azon tézis megnyilvánulásának tekinthető, miszerint az immunitás felfüggesztéséhez annak jogosultjának, vagyis az államnak a hozzájárulása szükséges. A Statútum ratifikálásával a részes tagállam hozzájárulását adja egy esetleges büntető eljárás lefolytatására az állami hierarchiájában legmagasabb pozíciót betöltő tisztviselöivel szemben. ${ }^{52} \mathrm{Az}$ immunitás felfüggesztése az ICC működésének effektív biztosítása érdekében vertikális és horizontális relációban értelmezendő. ${ }^{53}$

Kijelenthető tehát, hogy a 27. cikk a büntetőjogi felelősség problémáját taglalja, míg az immunitás, mint ahogy azt korábban említettük, eljárásjogi kérdésnek tekintendő. ${ }^{54}$ Ezt az álláspontot tükrözi a nemzetközi büntetőbíróságok gyakorlata, mivel statútumukat az adott bíróság természetével összhangban értelmezték. ${ }^{55} \mathrm{Az}$ immunitás irrelevanciájának indoka ezért nem az adott paragrafusban keresendő, hanem magának a bíróságnak a természetében, mely kívül áll a szorosan értelmezett államok közötti kapcsolatokon, míg az immunitás intézménye jellemzően az utóbbi kategóriában értelmezhető. ${ }^{56}$ Amíg a részes tagállamok közötti kapcsolatok tekintetében különös problémába nem ütközünk, addig a helyzet merőben

\footnotetext{
50 i.m. TRIFFTERER, 2016. 791.o.

51 i.m. SCHABAS, 2010. 449.o.

52 i.m. TRIFFTERER, 2016. 1607.o.

${ }^{53}$ LIND, 2016.

54 Difference Relating to ImMunity from Legal Process of a Special RAPPORTEUR OF THE COMMISSION OF HUMAN RIGHTS, 1999. 63.o.

55 KitTiCHAISAREE, 2001. 261.o.

56 ProseCuTOR V RADISLAV KRSTIĆ, 2003. 26.o.
} 
más azon államok esetében, amelyek nem ratifikálták a Statútumot. Fontos kiemelnünk, hogy e lehetőség a szerződés szövegének megfogalmazása során éles ellenállásba ütközött. A Statútum, mint nemzetközi szerződés az 1969. évi szerződések jogáról szóló bécsi egyezmény 34. cikk alapján nem állapíthat meg kötelezettségeket egy harmadik ország terhére annak beleegyezése nélkül, ezáltal nem foszthatja meg tisztviselőit mentelmi jogától. ${ }^{57}$ Jóllehet, a Statútum 89 . cikke rögzíti az ICC-vel való együttmúködés kötelezettségét, melynek keretében köteles elfogni és kiadni az ICC-nek a területén tartózkodó körözött személyt, addig a 98. cikk tovább árnyalja a képet harmadik államok esetében.

\subsection{A Statútum 98. cikke}

A Statútum szövegének létrehozása során a többi rendelkezéstől eltérően a 98. cikk megszövegezésére arányaiban kevesebb idő jutott, aminek oka, hogy talán ez a szakasz kapta a legkisebb politikai figyelmet. ${ }^{58}$ Ugyanakkor a rendelkezés jelentősége az évek folyamán felértékelődött. Egyrészt 98. cikk (1) bekezdésének alkalmazása az al-Bashir ügyben számos probléma forrásaként szolgált, másrészt az Előkészítő Bizottság 2000. évi ülésszakán az Egyesült Államok a 98. cikk rendelkezései alapján kísérelte meg az ICC joghatóságával kapcsolatos kérdések tisztázását egy Washingtonnak megfelelő kompromisszum létrehozása érdekében. ${ }^{59}$ A 98. cikk fontossága az olyan kérelmek eseteiben keresendő, amikor a kérelmezett államnak a nemzetközi jogból származó egyéb kötelezettségivel ütközik az ICC megkeresése, különös tekintettel a 27. cikk rendelkezéseire. Főszabály szerint a hivatalos minőség nem képezheti az ICC joghatóságának gátját. Ám, mivel az ICC önálló erőszakszervezettel nem rendelkezik és a részes tagállamok együttmúködésétől függ az eljárás lefolytatásának a lehetősége, így a meghatározott feltételek teljesülése esetén a 98. cikk gátolhatja joghatóságának gyakorlását egyes állami hivatalt betöltő személyekkel szemben. A további vizsgálatok lefolytatása érdekében a 98. cikk (1) bekezdés két rendelkezésének fogalmi meghatározása szükséges.

A „nemzetközi jogi kötelezettség” fordulat a 98. cikk (1) bekezdésének esetében a Tárgyalás Előkészítő Tanács olvasatában nem érinti az

\footnotetext{
57 i.m. SCHABAS. 2011. 450.o.

58 i.m. TRIFFTERER, 2016. 2120.o.

${ }^{59}$ CANETTI, 2001. 32.o.
} 
immunitás kérdéskörét. ${ }^{60}$ Másfelől viszont, ha az „államok mentessége, vagy egy harmadik államhoz tartozó személy diplomáciai mentessége” kitétellel együttesen értelmezzük, más eredményre juthatunk. Az államok mentessége kifejezés jelen esetben lefedi mind a funkcionális, mind a személyi immunitás intézményét. Ezt az értelmezést erôsíti meg a Nemzetközi Jogi Bizottság állásfoglalása, amely szerint minden esetben az állam áll az említett mentelmi jogosultságok mögött. ${ }^{61}$ Annak érdekében, hogy feltárjuk a 98. cikk alkalmazásának alanyi körét, tisztáznunk kell a „harmadik állam” kifejezés tényleges jelentését.

A nyelvtani értelmezése alapján két jelentés adható: egyrészt az 1969es Bécsi Egyezmény terminológiája szerint olyan államot jelent, amely „nem részese a szerződésnek”, másrészt pedig egy olyan állam, amely „eltér a kérelmezett államtól". ${ }^{62} \mathrm{Az}$ utóbbi megközelítést erôsíti meg az ICC Tárgyalás Előkészítő Tanácsa (a továbbiakban: TET) értelmezése. ${ }^{63}$ Amennyiben az ICC úgy látja, hogy egy megkeresés esetén a megkeresett államnak nemzetközi jogba ütköző tevékenységet kéne végrehajtania vagy mentességről való lemondás szükséges egy másik állam részéről, diszkrecionális döntési jogkörébe tartozik, hogy megkísérli-e a kérelmezettől eltérő állam hozzájárulásának a megszerzését. Ugyanakkor, ha letartóztatási parancsot kíván kibocsátani, úgy köteles ezen államot megkeresni annak érdekében, hogy lemondjon a tisztviselőjét megillető immunitás jogáról, s csupán ezt követően kérhetô a megkeresett állam együttműködése. ${ }^{64}$ Ennek megfelelően a harmadik állam lemondó nyilatkozatának megszerzése sine qua non feltételnek tekinthető a letartóztatási parancs és az együttmúködési kérelem kibocsátása személyi immunitást élvező személyek tekintetében. Ennek hiányában a megkeresett állam normaütközésbe keveredne nemzetközi jogi kötelezettségeivel, amelynek elkerülése a 98. cikk tárgya és célja. A 98. cikk (1) bekezdése nem ad iránymutatást arra vonatkozólag, hogy mi a teendó abban az esetben, ha az ICC-nek nem állnak rendelkezésre a megfelelő információk. Ilyen esetben az ICC eljárását szabályozó Eljárási és Bizonyítási Szabályainak 5. pontja értelmében a megkeresett államnak kell tájékoztatnia a fenn álló normaütközésekkel kapcsolatban. ${ }^{65}$

\footnotetext{
60 i.m. MALAWI, 2011., 20.o.

61 i.m. IMMUNITY OF STATE OFFICIALS, 2008. 94.o.

62 i.m. PEDRETTI (2015) 277.

63 i.m. MALAWI, 2011. 18.o.

${ }^{64}$ SAROOSHI, 1999. 432.o.

${ }^{65}$ Rules of Procedure AND EVIDENCE, 2013.
} 
A fentebb ismertetettek alapján láthatjuk, hogy a 27. cikk (2) bekezdés megszünteti a nemzetközi bűncselekményekkel megvádolt személyek immunitását az ICC eljárásának tekintetében, míg a 98. cikk (1) bekezdés megtiltja, hogy együttműködésre hívjon fel egy részes tagállamot, amennyiben ez a kérelem a kérelmezett által harmadik ország irányába fennálló nemzetközi szokásjogi kötelezettségének megsértéséhez vezetne. ${ }^{66}$ Erre az összefüggésre - számos részes tagállam és jogtudós értelmezésében - csupán harmadik államok hivatkozhatnak, míg részes tagállamok nem bújhatnak a két rendelkezés közötti ellentét mögé, amennyiben hivatalos pozíciót betöltő állampolgára egy másik állam területén tartózkodik. ${ }^{67}$

\subsection{A 27. és 98. cikkek kollíziója}

A 27. és a 98. cikk között egyértelmű feszültség uralkodik. Amíg a 27. cikk felfüggeszti az immunitás intézményét az ICC által foganatosított aktusok tekintetében, addig a 98. cikk mindezt fenntartja a nemzeti hatóságok vonatkozásában. Ugyanakkor Dapo Akande megközelítésében a 27. cikk által deklarált tézis egyaránt vonatkozik a nemzeti hatóságok által foganatosított aktusokra is. ${ }^{68}$ Ennek oka arra vezethetô vissza, hogy az első értelmezés alkalmazása a 27. cikket részben értelmetlenné tenné, ezáltal működésképtelenné válna. Mivel az ICC önálló erőszakszervezettel nem rendelkezik, ezért a tagállamok nemzeti hatóságaira van utalva. ${ }^{69}$ Ezáltal egy letartóztatási parancs kibocsátása esetén egy részes tagállam annak végrehajtásával nemzetközi jogi kötelezettségeivel ellentétes magatartást tanúsítana, mivel egy immunitással rendelkező személyt fosztana meg személyi szabadságától. A 27. cikk ily módon történő értelmezése által jutunk el a két cikk között uralkodó feszültség lényegéhez. Amennyiben a 27. cikket oly módon értelmezzük, hogy az az ICC eljárása mellett vonatkozik a nemzeti hatóságokra is, a 98. cikk tartalma kiüresedik. A nemzetközi szerződések effektív értelmezésének elve alapján egy rendelkezés sem értelmezhető oly módon, hogy az tartalom nélkül maradjon. ${ }^{70}$ Ennek megfelelően a két cikk megfelelő értelmezése alapján különbséget kell tennünk a szerződésben részes és nem részes államok vezetőit meg illető

\footnotetext{
66 i.m. CASSESE, 2008. 990.o.

${ }^{67}$ WIRTH, 2001. 429.o.

68 AKANDE, 2009. 338.o.

${ }^{69}$ i.m. AKANDE, 2004. 420.o.

${ }^{70}$ GARDINER, 2010. 160.o.
} 
mentelmi jog között. Következésképpen a két paragrafus kapcsolata két irányba ágazik.

Az első esetben a Statútum 27. cikkének (2) bekezdése nyer alkalmazást, így a 98. cikk (1) bekezdésében definiált normaütközés megállapítására nincs lehetôség, mivel a ratione materiae és personae immunitás nem hívható fel. ${ }^{71}$ Abban az esetben, ha ezt a megközelítést valamely részes állam vitatná, úgy külön megkeresésre nincs szüksége, mivel a szerződő fél a Statútum ratifikálásával automatikusan beleegyezését adta. ${ }^{72}$

Az utóbbi esetben a 27. cikk nem értelmezhető oly módon, mint egy általános lemondás, mivel annak az érintett állam általi ratifikálása nem történt meg. ${ }^{73} \mathrm{Az}$ 1969-es Bécsi Egyezmény rendelkezése értelmében a Statútum, mint nemzetközi szerződés nem hozhat létre kötelezettségeket egy nem részes állam terhére annak hozzájárulása nélkül. Ennek megfelelően a 98. cikk explicit módon lehetôséget nyújt a részes államok számára, hogy garantálják a nem részes államokat megillető immunitást. Ebben az esetben az ICC a 21. cikk (1) bekezdés (b) pontjának megfelelően ,az ügyben alkalmazandó egyezményeket és a nemzetközi jog alapelveit és szabályait" alkalmazza a felmerülő norma ütközés feloldása érdekében, különös tekintettel a nemzetközi szokásjogra. Ezen a ponton, mint ahogy azt már korábban tettük, különbséget kell tennünk a funkcionális és a személyi immunitás között.

Ahogy azt az 1965. évi a diplomáciai kapcsolatokról szóló Bécsi egyezmény 39. cikke kifejti, a funkcionális immunitás egy kiváltságokat és mentességeket élvező személy hivatalos tevékenységéhez kapcsolódik, amely azt követően is fenn marad, amikor az érintett személy megbízatása véget ér. Ugyanakkor, a nemzetközi büntetőjogon belül e mentesség nemzetközi bủncselekmények esetében relevanciával nem bír. A nürnbergi perek óta egy konzekvens nemzetközi és nemzeti gyakorlat erősíti meg ezen állítás nemzetközi szokásjogi gyökereit. Ennek megfelelően, a nemzetközi jogirodalom álláspontja egyértelmú annak tekintetében, hogy a 27. cikk (2) bekezdésének a funkcionális immunitást érintő kérdése a nemzetközi szokásjog deklaratív megnyilvánulásának tekinthető. ${ }^{74}$

Láthatjuk, hogy míg az immunitás első válfajánál különösebb problémába nem ütközünk, addig ez nem mondható el a személyi

\footnotetext{
71 i.m. SCHABAS, 2010. 1404.o.

72 i.m. MALAWI, 2011. 18.o.

73 i.m. AKANDE, 2004. 421.o.

74 LIND, 2016.
} 
immunitást élvező személyekrôl. Ahogy azt az ICJ a letartóztatási parancs ügyben kifejtette, a nemzetközi közjog nem ismer kivételt a ratione personae mentelmi jog alól a nemzeti hatóságok előtt. ${ }^{75}$ Ezzel egy időben azonban kimondta, hogy a személyi immunitás jogosultságával rendelkező személy alanya lehet egy nemzetközi büntetőbíróság eljárásának, amely megnyitotta a kaput a nemzetközi büntetőjogi felelősség irányába. Ezt az álláspontot fejlesztette tovább az ICC TET döntése, amely elismerte a személyi immunitás nemzetközi szokásjogban kialakult kivételeit, amely a részes tagállamoknak az ICC-vel való együttmúködésére egyaránt alkalmazandó, ezáltal a 98. cikkben szabályozott norma ütközés esete nem áll fenn. ${ }^{76}$

\section{KONKLÚZIÓ}

A fent kifejtettek alapján látható, az ICC felállítása a nemzetközi büntetőjog egyik legnagyobb eredménye, ugyanakkor egy általános, minden államra kiterjedő joghatósággal rendelkező fórum szerepének betöltésére nem képes. Egyrészt nemzetközi szerződés alapján jött létre, amely annak természetéből adódóan kizárólag a részes államokra állapíthat meg kötelezettségeket, másrészről maga a Statútum is felismeri a harmadik államok speciális helyzetét, így önmagával ellentmondásba kerülve gátolja a joghatóságának gyakorlását. Ezen kollízió feloldására az ENSZ Biztonsági Tanácsa lenne képes, azonban ahogy az az Al-Bashir eset során is bebizonyosodott, a hatékony fellépés lehetősége politikai okokból adódóan még várat magára.

\section{FELHASZNÁLT IRODALOM}

AветZ, Отто (1951): French Cour de Cassation, Revue Critique de Droit International Privè 1951/41

AFFIRMATION OF THE PRINCIPLES OF INTERNATIONAL LAW RECOGNIZED BY THE CHARTER OF THE NuRnberg TRIBUnAL (1946), (11 December 1946) A/RES/1/95. Elérhető: http://legal.un.org/avl/pdf/ha/ga 95I/ga $95-\mathrm{I}$ ph e.pdf

\footnotetext{
75 i.m. CONGO, 2002. 53-58.o.

76 i.m. MALAWI, 2011. 37-44.o.
} 
AKANDE, DAPO (2009): The Legal Nature of Security Council Referrals to the ICC and its Impact on Al Bashir's Immunities, JICJ 2009/7.

Elérhető: https://academic.oup.com/jicj/articleabstract $/ 7 / 2 / 333 / 902217$ ?redirectedFrom=fulltext DOI azonosító: https://doi.org/10.1093/iicj/mqp034

ASSEMBLY OF THE AFrICAN UNION (2009), Thirteenth Ordinary Session (13 July 2009). Elérhető:

https://au.int/sites/default/files/decisions/9560assembly en 13 july 2009 auc thirteenth ordinary session decisions declarations message congratulations motion 0.pdf

CANETTI, ELIAS (2001): International and National Prosecution of Crimes Under International Law, Berliner

CASSESE, ANTONIO (2008): International Criminal Law, Oxford University Press. DOI azonosító: https://doi.org/10.1111/j.1748121X.2008.00116 4.x

CAssese, ANTONIO (2002): When May Senior State Officials Be Tried for International Crimes? Some Comments on the Congo v Belgium Case, EJIL 2002/13. Elérhető: http://www.ejil.org/pdfs/13/4/1564.pdf CHARTER OF THE InTERNATIONAL MilitARY TRIBUnAL (1945), (8 August 1945) UNGA Res. A/CN.4/5

CONVENTION AgAinst TORTURE AND OtHER CRUEL, INHUMAN OR Degrading TREATMENT OR PUNISHMENT (1984), (10 December 1984) UNGA Res. 39/46. Elérhető: https://www.ohchr.org/en/professionalinterest/pages/cat.aspx

DANILENKO, GENNADY M. (2000): The Statute of the International Criminal Court and Third States, Michigan Journal of International Law 2000/21. Elérhető:

https://repository.law.umich.edu/mjil/vol21/iss3/3/

DiFFERENCE RELATING TO IMMUNITY FROM LEGAL PROCESS OF A SPECIAL RAPPORTEUR OF THE COMMISSION OF HUMAN RighTS (1999), ICJ Advisory Opinion of 29 April 1999. Elérhető: https://www.icjcij.org/files/case-related/100/100-19990429-ADV-01-00-EN.pdf

FrAY, MARC - KUNKEL, SÖNKE - UNGER, CORINNA R. (2014):

International Organizations and Development, 1945-1990, Palgrave Macmillan

GARDINER, RICHARD K. (2010): Treaty Interpretation, OUP 
JURISDiCTIONAL IMMUNITIES OF THE STATE (2012), (Germany v Italy: Greece intervening) ICJ Judgment of 3 February 2012. Elérhetô: https://www.icj-cij.org/en/case/143

KALECK, WolfGANG - RATNER, MiCHAEL - Singelnstein, TOBiAS WEIsS, PETER (2007): International Prosecution of Human Rights Crimes, Springer. DOI azonosító: 10.1007/978-3-540-46278-1 KITTICHAISAREE, KRIANGSAK (2001): International Criminal Law, OUP LATTMANN TAMÁs (2011): A nemzetközi büntetőbírói fórumokkal való együttmúködés lehetôsége vagy lehetetlensége a magyar jogi előírások alapján - különös tekintettel a Nemzetközi Büntetőbíróságra, Kül-Világ, 2011/8. Elérhető: https://matarka.hu/cikk list.php?fusz=97107 LAUCCI, CyRIL (2006): Digest Of Jurisprudence of the Special Court for Sierra Leone, Nijhoff

Lauterpacht, Elihu - GreENWOOD, C.J. - OpPENHEIMER, A. G. (1996): International Law Reports, CUP

Lind, CAmilla (2016): Article 27, Commentary Rome Statute: Part 3 (30 June 2016). Elérhető: https://www.casematrixnetwork.org/cmnknowledge-hub/icc-commentary-clicc/commentary-romestatute/commentary-rome-statute-part-3/

Lind, CAMILA (2016): Article 98, Commentary Rome Statute: Part 9 (30 June 2016). Elérhetô: https://www.casematrixnetwork.org/cmnknowledge-hub/icc-commentary-clicc/commentary-romestatute/commentary-rome-statute-part-9/\#c2175

PAPP NiKOLETT (2015): Államfők elleni eljárások a nemzetközi bíróságok előtt - az államfői immunitás múltja, jelene, jövője, In: KARLOVITZ János Tibor (szerk.), Fejlődő jogrendszer és gazdasági környezet a változó társadalomban, International Research Institute. Elérhetô: http://www.irisro.org/tarstud2015aprilis/15PappNikolett.pdf

PEDRETTI, RAMONA (2015): Immunity of Heads of State and State Officials for International Crimes, Nijhoff

Prosecutor V. Slobodan Milosevic (2001), (Decision on Preliminary Motions) IT-02-54 (8 november 2001). Elérhető: https://www.icty.org/en/case/slobodan milosevic

Prosecutor V. RADISLAV KRISTIC (2001), (Decision n Application for Subpoenas) IT-98-33 (8 november 2001). Elérhető: https://www.icty.org/en/case/krstic

ProseCutOR V TiHOMIR BLAŠKIĆ (1997), (Judgement) IT-95-14-A (18 July 1997). Elérhetô: https://www.icty.org/en/case/blaskic 
REYDAMS, LUC - WOUTERS, JAN - RYNEGAERT, CEDRIC (szerk) (2012): International Prosecutors, OUP

RoAch, Steven C. (2013): How Political is the ICC? Pressing Challenges and the Need for Diplomatic Efficacy, Global Governance 2013/19. Elérhetô:

https://www.jstor.org/stable/24526391?seq=1\#metadata info tab con tents

Rules of Procedure AND EvidenCe (2013), International Criminal Court. Elérhető: https://www.icc-cpi.int/iccdocs/pids/legaltexts/rulesprocedureevidenceeng.pdf

SAROOSHI, DANESH (1999): The Statute of the International Criminal Court, The International and Comparative Law Quarterly 1999/48; https://www.cambridge.org/core/journals/international-andcomparative-law-quarterly/article/statute-of-the-international-criminalcourt/49100DDDCF9CF4D2938F192DD6F25E94

SCHUERCH, Res (2017): The International Criminal Court at the Mercy of Powerful States, Springer. DOI azonosító: 10.1007/978-94-6265-192-0 SPINEDI, MARINA (2002): State responsibility v individual responsibility for international crimes, tertium non datur?, EJIL 2002/13. Elérhető: http:/ $/$ www.ejil.org/article.php?article $=1566 \&$ \&issue $=32$

SuMmers, MARK A. (2006): Immunity or Impunity? The Potential Effect of Prosecutions of State Officials for Core International Crimes in States Like the United States That Are Not Parties to the Statute of the International Criminal Court, Brooklyn Journal of International Law 2006/31. Elérhető:

https://brooklynworks.brooklaw.edu/cgi/viewcontent.cgi?article $=1273$ \&context=bjil

The Prosecutor V. Omar Hassan Ahmad Al Bashir (2011), (Corrigendum) ICC-02/05-01/09 (13 December 2011). Elérhető: https://www.icc-cpi.int/CourtRecords/CR2011 21750.PDF

TRIFFTERER, OTTO (2008): Commentary on the Rome Statute of the International Criminal Court, Beck Hart

UN PRESS RELEASE (1998), L/2889 (20 July 1998). Elérhető: https://www.un.org/press/en/1998/19980720.12889.html

United States of America v MANuel Antonio Noriega, How Does Law Protect in Law. Elérhető: https://casebook.icrc.org/casestudy/united-states-united-states-v-noriega. 
VARGA RÉKA (2006): A Római Statútum Jelentősége a Nemzetközi Jogban és a Nemzetközi Büntetőjogban, Iustum Aequum Salutare 2006/2. Elérhető:http://ias.jak.ppke.hu/hir/ias/200612sz/2006 12 2acta11.pdf

WirTH, STEFFEN (2001): Immunities, Related Problems, and Article 98 of the Rome Statute, Criminal Law Forum 2001/12. Elérhető: https://link.springer.com/article/10.1023\%2FA\%3A1016191426741 DOI azonosító: https://doi.org/10.1023/A:1016191426741

YEARBOOK OF THE INTERNATIONAL LAW COMMISSION (Volume II, 1950) A/CN.4/L.2.

Zappala, SALVATORE (2001): Do Heads of state in Office Enjoy Immunity from Jurisdiction for International Crimes? The Gaddafi Case Before the French Cour de Cassation, EJIL 2001/12. Elérhető:

http:/ $/$ www.ejil.org/article.php?article $=1534 \&$ issue $=36$ 